\title{
The absolute socioeconomic inequity attributable to smoking
}

Efraín Sánchez González ${ }^{1}$ and Fé Fernández Hernández ${ }^{{ }^{*}}$

${ }^{1}$ Faculty of Medical Sciences "10 de Octubre".

2 Faculty of Medical Sciences "10 de Octubre"

*Corresponding author: Fé Fernández Hernández, Faculty of Medical Sciences "10 de Octubre".

Received date: July 02, 2020; Accepted date: July 20, 2020; Published date: July 24, 2020

Citation: Fé F Hernández, Efraín S González, (2020) The absolute socioeconomic inequity attributable to smoking; Clinical Reviews and Clinical

Trials. 2(1); DOI: 10.31579/2693-4779/009

Copyright: @ 2020 Fé Fernández Hernández, This is an open-access article distributed under the terms of the Creative Commons Attribution License, which permits unrestricted use, distribution, and reproduction in any medium, provided the original author and source are credited.

\begin{abstract}
Background: Smoking has several consequences over the society and the economy at same time. Because of smoking smokers are reducing the life quality and life expectation too. That is the main cause of absolute socioeconomic inequity attributable to smoking. Objective: To characterize the absolute socioeconomic inequity attributable to smoking.

Materials and methods: Were used several theorical methods as the inductive - deductive and the comparative too. As empirical method was used the bibliographic research.

Results: Smoking is the main cause of the existence of this particular inequity form. That's why to eliminate the absolute socioeconomic inequity attributable to smoking is necessary focus the attention in the reduction of the tobacco consumption intensity as main explicative variable for personal smoker demand of health services because of smoking.

Conclusions: The absolute socioeconomic inequity attributable to smoking is showed by mortality and morbidity too. In both case the strategic to reduce the tobacco consumption must focus the attention as main way to control, reduce and eliminate the absolute socioeconomic inequity attributable to smoking
\end{abstract}

Key words: smoking, absolute inequity, control

\section{Background}

Smoking has several consequences over the society and the economy at same time. Because of smoking smokers are reducing the life quality and life expectation too. As consequence smokers are demanding more health services agreeing with the own tobacco consumption intensity. ${ }^{1}$

Resulting from these relations it shows antagonist relations between smokers and no-smokers accessing to the health services. This situation is given by the disparities caused by smoking in the Public health market and how people are accessing to these services. ${ }^{2}$

By other side, the reduction in the life expectation from smokers should carry to smokers' death in the labor active age. This consequence carries to overburdening the no-smoker people because of the socioeconomic cost associated to this labor productivity lose. ${ }^{3}$

In both case smokers and no-smokers are suffering the smoking social consequences given by all disparities caused by smoking in agree to the smokers number and the tobacco consumption intensity. These consequences have an especial representation in the absolute socioeconomic inequity attributable to smoking. The characterization of this particular inequity form will contribute to a better understanding from smoking socioeconomic consequences over the researching population. ${ }^{4}$

\section{Objective}

To characterize the absolute socioeconomic inequity attributable to smoking.

\section{Materials and methods}

Was done a descriptive research about the absolute socioeconomic inequity attributable to smoking. Were used several theorical methods as the inductive - deductive and the comparative too. As empirical method was used the bibliographic research.

\section{Results}

The absolute socioeconomic inequity attributable to smoking occurs when health services clients must leave the health market and then can't access to these services. This inequity form it show by mortality and morbidity too.

\section{The absolute socioeconomic inequity attributable to smoking by mortality}

The absolute socioeconomic inequity attributable to smoking by mortality has peculiar characteristic. In this case it is important to appointment that the overmortality because of smoking is determinants cause of this inequity form. The existence of this overmortality type is determining a social inequity given by the differences in life expectation between smokers and no-smokers people. Nevertheless, the absolute socio-

economic inequity attributable to smoking by mortality occurs if earlier death attributable to smoking represents a socioeconomic cost. Then, absolute socioeconomic inequity attributable to smoking by mortality is determined by the absolute labor productivity lose attributable to smoking. ${ }^{5}$

A peculiar form to measure this inequity form should be by accounting all opportunities costs attributable to smoking by earlier death attributable to smoking before retire age. For example, in Cuba 2011 the overmortality attributable to smoking in men was around 18.4 years. This determined an overmortality of 3.22 years respect to the retire age. As consequence, the Cuban economy didn't obtained close to 295 millions of pesos. ${ }^{6}$ 


\section{The absolute socioeconomic inequity attributable to smoking by morbidity}

The absolute socioeconomic inequity attributable to smoking by morbidity is given by forms covering the health services. These services may be covered by fiscal resources or privates resources. In this case only is considered as private services which are covered by insurance rate. ${ }^{7}$

The health services demand attributable to smoking are determined by tobacco consumption intensity and the smoker number. That's why smoking induces to increase the health services demand agreeing with tobacco consumption intensity and the smoker number. ${ }^{8}$

Increasing some of these variables health services demand should increase too and clients from the Public Health market should experiment an increasing from the health insurance rate. Clients who can't afford the new price agree with the particular service demanded should leave from the Public Health market. Thus is manifested the absolute socioeconomic inequity attributable to smoking by morbidity when the health services are covered by privates resources. ${ }^{9}$

When the health services demand is covered by fiscal resources smokers and no-smokers people are demanding these services agree with personal needs. Increasing tobacco consumption intensity and/or the smoker number the health services demand will increase too. The fiscal authorities should decide if are agreeing in cover the increasing demand attributable to smoking. Economic resources are always limited and often will not possible cover the new demand. Consequently not all demanded services should able and a significant client number will haven't access to the demanded services. At same time smokers will increase the frequency demanding the health services agree with the tobacco consumption intensity. That's why no-smoker people should experiment least access to health services because of smoking. ${ }^{10}$

\section{Public resources vs. private resources}

All goods and services markets are imperfect. The Public Health market too. Given the antagonist relation between privates resources and fiscal resources covering the health services demand because of smoking, to control, reduce and eliminate the absolute socioeconomic inequity attributable to smoking the most important thing isn't how cover the health services demand because of smoking. This discussion doesn't solve the main cause of this inequity form. ${ }^{11}$

Smoking is the main cause of the existence of this particular inequity form. That's why to eliminate the absolute socioeconomic inequity attributable to smoking is necessary focus the attention in the reduction of the tobacco consumption intensity as main explicative variable for personal smoker demand of health services because of smoking. ${ }^{12}$

By other side smoking is affecting several economic and social sectors at same time. Then, the whole society and not only the Public Health must be protagonist for all strategic controlling and reducing smoking. Independently from who is covering the health services demand attributable to smoking the most important think is have a whole knowledge about smoking consequences and play an active role controlling, reducing and eliminating the absolute socioeconomic inequity attributable to smoking. ${ }^{13}$

\section{Conclusion}

The absolute socioeconomic inequity attributable to smoking is showed by mortality and morbidity too. In both case the strategic to reduce the tobacco consumption must focus the attention as main way to control, reduce and eliminate the absolute socioeconomic inequity attributable to smoking.

\section{References}

1. Fernández Hernández F., Sánchez González E. (2019). La carga económica del tabaquismo (2019). Barcelona: Editorial Académica Española.

2. Fernández Hernández F, Sánchez González E. (2019). The socioeconomic inequity attributable to smoking. Journal of Medical Practice and Review [Internet] [citado 2019 Jun 15]; 3(6): 559 - 562.

3. Sánchez E, Fernández F. Costo social por pérdida absoluta de productividad laboral. RevistaCubana de Salud y Trabajo 2018; 19(1):33-9.

4. Fernández Hernández F., Sánchez González E. (2020). The Social and Economic Inequity from Smoking in Cuba. Annals of Medical \& Surgical Case Reports. 2(2). AMSCR-100037

5. Sánchez González E., Fernández Hernández F. (2016). La pérdida de productividad laboral atribuible al tabaquismo. Revista Cubana de Salud y Trabajo. 17(2):57-60.

6. Sánchez González E., Fernández Hernández F. (2011). Costo de oportunidad por muerte prematura de fumadores activos cubanos en el año. Revista Cubana de Salud y Trabajo. 2017; 18(2):26-31.

7. Sánchez González E, Fernández Hernández F. (2017) El rol de las autoridades fiscales en el control del tabaquismo. Rev. Ciencias Médicas de Pinar del Río. Mayo-junio, vol 21(3)362-367.

8. Fernández Hernández F, Sánchez González E. (2017) Carga epidemiológica vs carga económica del tabaquismo por morbilidad. Rev. Ciencias Médicas de Pinar del Río. Marzo -abril,; vol. 21(2)210-216.

9. Fernández Hernández F, Sánchez González E. Algorithm to calculate the smoking economical burden in active and passive smokers. MedCrave Journal of Toxicology. 2018; 4(6):373-375.

10. Sanchez Gonzalez E, Fernandez Hernandez F. The smoking fiscal space in Cuba. J Clin Med Res. 2019; 1(3):1-5.

11. Arredondo A, Recaman AL, Pinzon C, Azar A. Financial consequences from smoking-related diseases in middle-income countries: Evidence and lessons from Mexico. Int J Health Plann Mgmt. 2018; 33:e454-e463.

12. Fernández Hernández F and Sánchez González E (2019) Economic8. Inequity Attributable to Smoking Ratio's for the Public Health. HealthEconOutcome Res Open Access 5: 1-4.

13. Abascal Winston, Lorenzo Ana. Impacto de la política de control de tabaco en población adolescente en Uruguay. Salud pública Méx [revista en la Internet]. 2017 [citado 2019 Ago 08]; 59( Suppl 1 ): 40-44. 